\title{
Construction and validation of a virtual learning object for the teaching of peripheral venous vascular semiology
}

\author{
Construção e validação de um objeto virtual de aprendizagem para o ensino da semiologia \\ vascular venosa periférica \\ Construcción y validación de un objeto virtual de aprendizaje para la enseñanza de la semiología \\ vascular venosa periférica
}

\author{
Bárbara Gadioli ${ }^{1}$ \\ Francine Lima Fulquini ${ }^{1}$ \\ Luciana Kusumota $^{1}$ \\ Fernanda Raphael Escobar Gimenes ${ }^{1}$ \\ Emília Campos de Carvalho ${ }^{1}$
}

1. Universidade de São Paulo.

Ribeirão Preto, SP, Brasil.

\begin{abstract}
Objective: To construct and evaluate the SEMIOVAPE - a Virtual Learning Object for teaching of peripheral venous vascular semiology - based on ergonomic, pedagogical and usability criteria. Method: Methodological study, whose participants were experts in Nursing, Computer Science and Nurse undergraduate student. For the construction and validation of the Object, six steps were followed: educational design; computational modeling; environment implementation; ergonomic, pedagogical, and usability evaluation. Results: The Object was built having the characteristic of valuing student's autonomy and approached contents of anatomy and physiology, clinical reasoning and clinical examination. Concerning the ergonomic and pedagogical evaluations, the Object obtained high acceptance rates $(66.70 \%$ and $70.12 \%$, respectively), as for usability, all participants considered it very useful and were certainly satisfied (95\%). Conclusions and implications: The Object is suitable to be used as an alternative source of teaching peripheral venous semiology.
\end{abstract}

Keywords: Teaching; Nursing; Educational Technology; Physical Examination; Nursing Teaching and Semiology.

\section{Resumo}

Objetivo: Construir e avaliar quanto a critérios ergonômicos, pedagógicos e de usabilidade um Objeto Virtual de Aprendizagem para o ensino da semiologia vascular venosa periférica, o SEMIOVAPE. Método: Estudo metodológico, cujos participantes foram peritos da enfermagem, da informática e graduandos de enfermagem. Para construção e validação do Objeto foram seguidas seis etapas: design educacional, modelagem computacional, implementação do ambiente, avaliação ergonômica, avaliação pedagógica e avaliação da usabilidade. Resultados: $O$ Objeto foi construído tendo a característica de valorização da autonomia do aluno e abordou conteúdos de anatomia e fisiologia, raciocínio clínico e exame clínico. Quanto às avaliações ergonômica e pedagógica, o Objeto obteve elevados índices de aceitação ( $66,70 \%$ e $70,12 \%$, respectivamente), quanto à usabilidade, todos os participantes consideraram-no muito útil e ficaram certamente satisfeitos (95\%). Conclusões e implicações: $O$ Objeto é adequado para ser utilizado como método alternativo do ensino da semiologia venosa periférica.

Palavras-chave: Ensino; Enfermagem; Tecnologia Educacional; Exame físico; Ensino de Enfermagem e Semiologia.

\section{Resumen}

Objetivo: Construir y evaluar, en cuanto a criterios ergonómicos, pedagógicos y de usabilidad, un Objeto Virtual de Aprendizaje para la enseñanza de la semiología vascular venosa periférica, el SEMIOVAPE. Método: Estudio metodológico, cuyos participantes fueron expertos en Enfermería, Informática y estudiantes de pregrado de Enfermería. Para la construcción y validación del objeto, se siguieron seis pasos: diseño educativo; modelado computacional; implementación del ambiente; evaluación ergonómica; evaluación pedagógica y evaluación de la usabilidad. Resultados: El Objeto fue construido teniendo la característica de valorización de la autonomía del alumno y abordó contenidos de anatomía y fisiología, raciocinio clínico y examen clínico. En relación a las evaluaciones ergonómica y pedagógica, el Objeto obtuvo altas tasas de aceptación (66.70\% y $70.12 \%$, respectivamente), en cuanto a la usabilidad, todos los participantes lo consideraron muy útil y sin duda alguna estaban satisfechos (95\%). Conclusiones e implicaciones: El Objeto es adecuado para ser utilizado como un método alternativo de enseñanza de la semiología venosa periférica.

Palabras clave: Enseñanza; Enfermería; Tecnología Educacional; Examen Físico; Enseñanza de Enfermería y Semiología.
Corresponding author: Emília Campos de Carvalho. E-mail: ecdcava@usp.br

Submitted on 03/04/2018. Accepted on 06/25/2018.

DOI: 10.1590/2177-9465-EAN-2018-0043 


\section{INTRODUCTION}

The teaching-learning process in higher education, including nursing, has been influenced by the expansion of online education. This tendency allows the search for new knowledge in digital learning environments, encouraging the active participation of the student, with a model of collaborative, active and transforming education. ${ }^{1}$ The use of the Internet in the teaching-learning process stimulates the updating, communication and the qualification, generating positive influence on the scientific development of the student and, consequently, better performance in the profession, being essential the incorporation of educational technologies by the institutions, as alternative teaching methods in order to adapt to the current context of nursing students. ${ }^{2}$

The traditional method of teaching in semiology is considered fragmented and reductionist, with predominance of banking education. New alternatives that allow interactions and autonomy in this area of education ${ }^{3}$ and consequent break in the cycle of knowledge transfer to the student imposing passivity, nullifying their creativity and generating accommodation to the deposited content are needed. ${ }^{4}$

Previous studies have demonstrated efforts in the teaching of semiology and clinical reasoning through methods alternative to traditional ones, including practical guides, ${ }^{5}$ courses in virtual learning environments, ${ }^{6}$ videos and educational games, ${ }^{3}$ simulations ${ }^{7}$ and virtual learning objects. Promotion of educational dialogues among students in social networks were also found on literature. ${ }^{9}$

Virtual Learning Objects (VLO) are defined as a variety of didactic material (images, videos, games, websites, etc.) used in a teaching-learning process with technology base. ${ }^{10}$ The use of VLOs has a great capacity of dynamizing the teaching-learning process in several areas of nursing, making its implementation and evaluation important. ${ }^{11}$ In order for a VLO to be available adequately to its public, it is necessary to validate it with specialists in the study field and, in computer science, with ergonomic (media, functioning, appearance) and pedagogical (adequacy of content to the objective and public) criterias. ${ }^{12}$

Researches involving this resource in nursing education have demonstrated significant results, allowing student reflection and self-criticism. ${ }^{13,14}$ Since data collection is the starting point for clinical reasoning in nursing,${ }^{15}$ the development of VLOs that contribute to this stage of the process is relevant since the search for data using reliable methods and well-conducted clinical reasoning favor a safe practice. ${ }^{16}$

Among the organic systems observed in the data collection by the nurse, the peripheral venous system is highlighted, in which veins that drain the head, neck, upper and lower limbs are evaluated. ${ }^{17}$ The evaluation of the peripheral venous system is important, since it is frequently accessed in nursing practice to enable short or long-term medical treatments, diagnostic tests, and hemodynamic monitoring. ${ }^{18}$ In addition, we found in the literature diagnoses, results and nursing interventions that use the peripheral venous evaluation. ${ }^{19-21}$
The evaluation of the peripheral venous system allows the identification of clinical complications that may compromise the health status of the patient, including phlebitis, venous thromboembolism, chronic venous insufficiency and venous ulcer. Alteration of the jugular veins may suggest elevated central venous pressure or the presence of aneurysms. ${ }^{15}$ Through evaluation of upper and lower limbs it is possible to identify the venous pattern, changes in temperature, edema, and competence of the veins. ${ }^{15-22}$ Considering the complexity and relevance of the peripheral venous system, the undergraduate nursing student should be prepared to perform these data collection techniques.

In view of the need for new resources in the teaching of peripheral venous semiology and the benefits of using virtual objects, this study is justified in order to construct and validate a virtual learning object for the teaching of peripheral venous semiology to undergraduate nursing students, the SEMIOVAPE.

\section{METHOD}

This is a methodological study ${ }^{23}$ conducted in a nursing school in the interior of the state of São Paulo, in the period from 2016 to 2017, with experts in the area of Nursing $(n=3)$ and Computer Science $(n=3)$ and undergraduate students of Nursing $(n=20)$, target public of the object.

For the construction and validation of the SEMIOVAPE, six methodological steps were used: educational design; computational modeling; environmental implementation; ergonomic evaluation; pedagogical evaluation and usability evaluation. ${ }^{24}$ The project was approved by the Research Ethics Committee of the Institution (CAAE 588369916.0.0000.5393, on September $\left.21^{\text {st }}, 2016\right)$.

In the educational design stage, the target audience, the objectives, area, subarea and content worked, teaching-learning strategy, task types, degree of interaction, definition of work plan, activities and student and teacher roles were defined. ${ }^{24}$ The SEMIOVAPE is aimed at Nursing undergraduates and the main objective is teaching the data collection of a given system, including the interview and physical examination stages. In addition, it has as its area of study the vascular semiology, having as its theme the teaching of peripheral vascular venous semiology, on which the topics of content were selected: anatomy and physiology of the cardiovascular system, clinical complications, data collection, interview, physical examination and clinical relevance of the evaluation of this system.

The present object is not intended to replace the teacher or the classroom classes of semiology, but to complement the content seen in the classroom, serving as a method of study for the student.

In the computational modeling stage, the SEMIOVAPE project and its layout were defined, including the multimedia resources to be used, material elaboration, the definition of color standards and visual programming. In the object of the present study, images constructed by computer professionals under the supervision of the researcher were used. Adobe Illustrator ${ }^{\circledR}$ and Photoshop ${ }^{\circledR}$ programs were used to construct the images. 
The third stage of construction, called the implementation of the environment, involved the development of the object, with the combination of the schematization and the theoretical content. PowerPoint ${ }^{\circledR}$ and HTML5POINT ${ }^{\circledR}$ resources were used to save Microsoft Power Point ${ }^{\circledR}$ files in HTML format. Thus, the format of the object was made in HTML so that, after validation, it would be made available in the discipline of Semiology and Semio-Technique in the virtual learning environment Moodle, for students' access.

After completing the construction stages, SEMIOVAPE evaluation followed, with the first being those of ergonomic and pedagogical evaluation. Both stages involve expert evaluation and are intended to ensure that VLO is made available properly. The pedagogical evaluation involved an analysis of the coherence of the virtual learning object contents with the target audience and its adequacy to the teaching-learning proposal. This stage was carried out with three clinical nurses, with at least five years of experience, using an adapted instrument that evaluates the objectives, content, clarity, ease of use, attractiveness, grammar, and relevance, as well as having a space for comments and suggestions.

The ergonomic evaluation was performed with the six experts, clinical nurses, who also participated in the pedagogical evaluation and professionals in the area of Computer Science, also with at least five years of experience. For this stage, two adapted instruments ${ }^{25}$ were used, one for each professional area. The tool for information technology experts covered the following topics: page components, page grouping, menu titles, structure, icons, navigation, organization, content presentation and functionality. The instrument of ergonomic evaluation delivered to the nursing experts contained the evaluation of the following aspects: ease of navigation, clarity, presentation, functionality and appearance. In both instruments the experts should express whether they agreed with the items presented, ranging from "strongly disagree", "disagree", "agree", "strongly agree" and "do not know".

The last step was the evaluation of the usability, by the target public, Nursing graduates who had already completed the discipline of Semiology and Semio-Technique offered by the Institution of origin. A convenience sample was used by the snowball method. ${ }^{23}$ At this stage, an adapted instrument ${ }^{26}$ was used to evaluate the navigation experience, object recommendation, content adequacy, motivation, satisfaction and difficulties observed with the SEMIOVAPE. The items of the instrument were formed by multiple choice questions, with answer options depending on the item, with the exception of the open question related to the difficulties in navigation.

The invitation to the experts and the target public was made by the main researcher, through which the collection was scheduled based on the availability of the participant. On the scheduled day, the researcher presented the objectives of the research and delivered the Term of Free and Informed Consent (TFIC), composed of two signed copies. After acquiescence, the participants appreciated the SEMIOVAPE in a notebook and answered the respective instrument to the participated stage.
Data were entered and analyzed in the IBM software Statistical Package Social Science (SPSS) ${ }^{\circledR}$, version 17.0 for Windows, using distribution and frequency. The SEMIOVAPE, to be considered validated, should obtain $\geq 80 \%$ of the indication (in the set of alternatives "I agree" and "I strongly agree" of the evaluation instrument) by the experts.

\section{RESULTS}

\section{Construction of the SEMIOVAPE}

In the educational design stage, from the selected themes, an expansive search was made in bibliographies of the area of anatomy, physiology, semiology and clinical reasoning. Materials used included recently published books and scientific articles. The selected contents were didactically divided into two parts, constituting the VLO Main Menu (Figure 1).

In the topic of anatomy and physiology, are recalled basic aspects about the blood vascular system, the particularities of the veins and their functions. In this stage, the student finds five subtopics: cardiovascular system, differences between arteries and veins, structure of the veins, venous valves and main veins of the body. The latter exemplified in Figure 2.

In the topic of clinical complications, we find the pathophysiology of four conditions that affect the venous system: phlebitis, venous thromboembolism, chronic venous insufficiency and venous ulcer. In each condition, images are arranged that allow the student's easy understanding.

The topic of data collection portrays the importance of its steps, the interview and the physical examination. The topic of the interview exposes the contents necessary to perform the anamnesis, including stages of the interview, analysis of symptoms and specific interview of the venous system. At the physical examination stage, the student has access to the contents of the semio-technical inspection of the jugular veins and inspection and palpation of the main veins of the upper and lower limbs, including special maneuvers, in addition to a classification of veins present in the Brazilian literature. ${ }^{18}$ The following figure (Figure 3) shows the edema evaluation screen.

At the end of each item, multiple choice questions are inserted about the contents addressed in each phase of SEMIOVAPE, followed by the template containing the correct response. The questions were elaborated in order to allow the self-evaluation of the student, valuing their autonomy and critical sense about the learning process.

The topic "Relevance" addresses the clinical application of the contents learned in the object. Nursing diagnoses, according to Taxonomy II of the NANDA-I, were used, as well as results and nursing interventions related to the venous system. The object has a complementary reading topic, in which the student finds reading suggestions that supplement and deepen the content addressed.

The "Help" module is available in the main menu and the student can access it at any time to clarify doubts about its use and obtain technical information about the object. 
Figure 1. Welcome screen of SEMIOVAPE. To the left, the main menu.

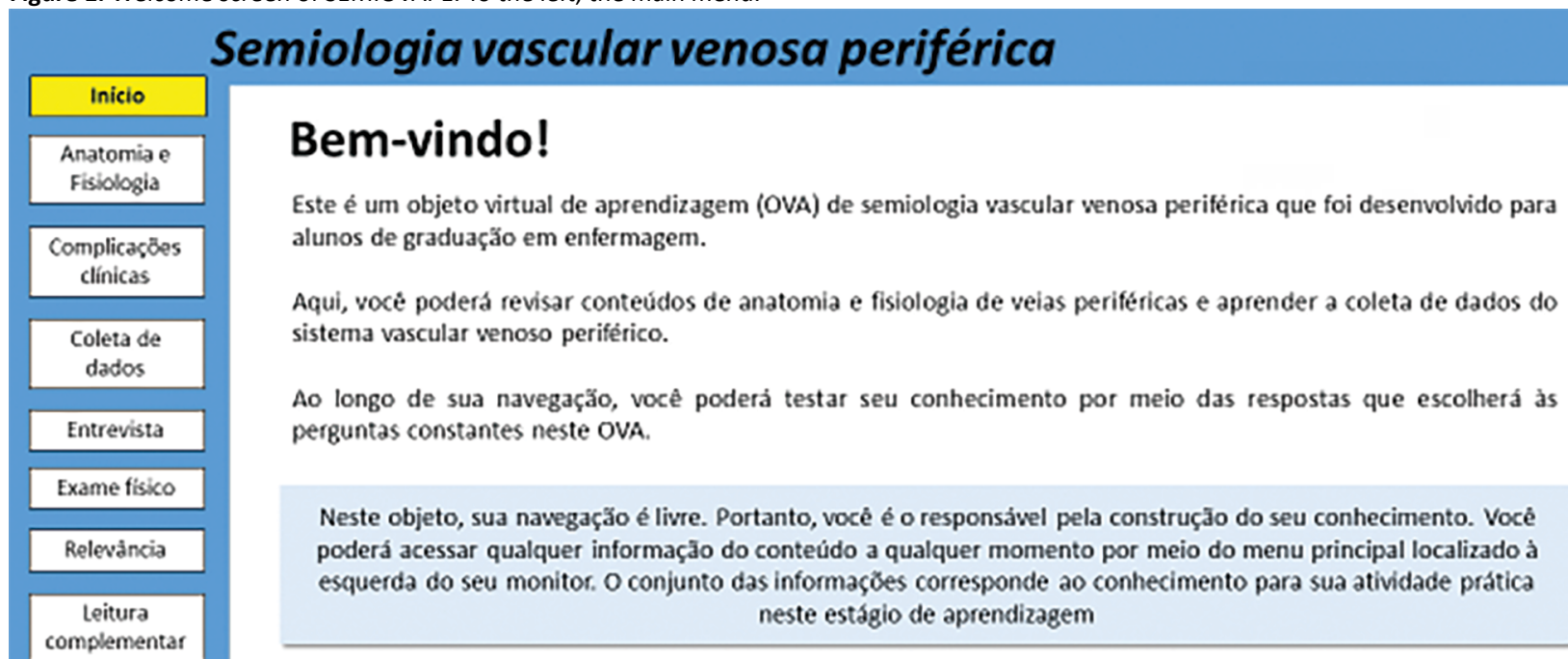

Inicie sua navegaçăo clicando em alguma opça do menu principal.

Esperamos que vocé tenha um ótimo aprendizadol

Figure 2. Anatomy and Physiology. Main veins.

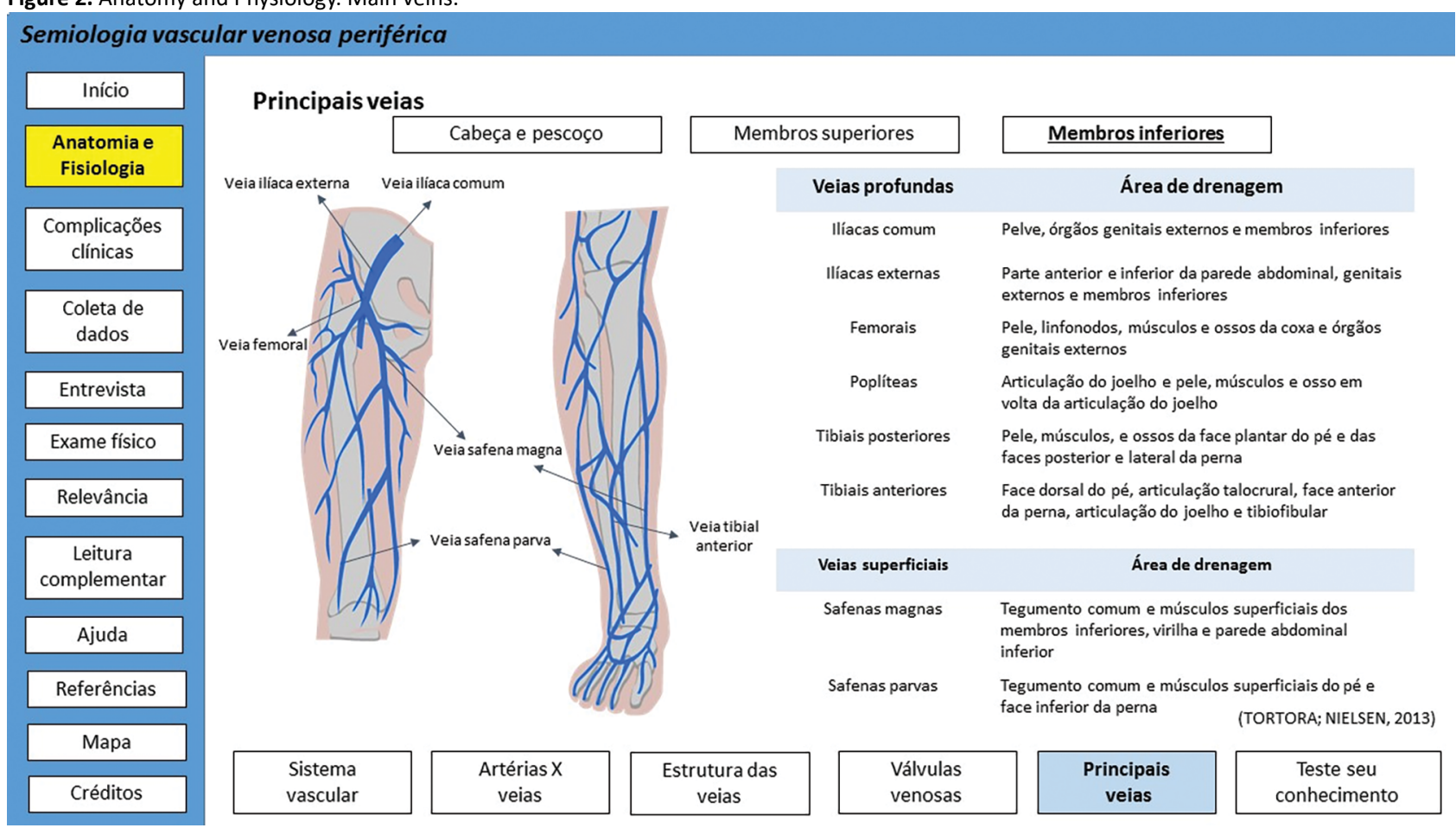


Figure 3. Physical examination. Evaluation of edema.

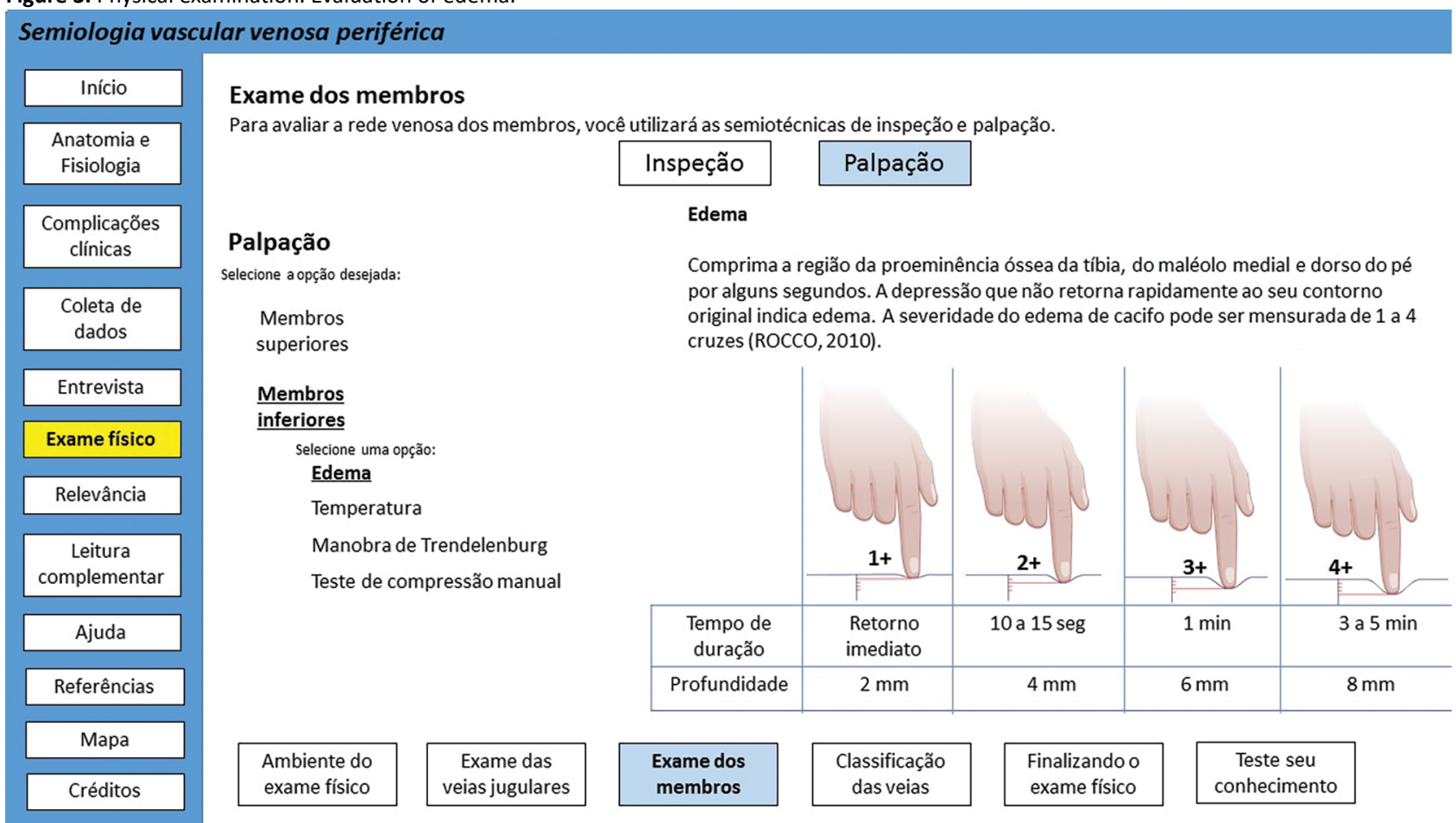

After the preparation of the text with the theoretical content (first stage), the SEMIOVAPE layout was set up. For the production of the pages of the object, the PowerPoint ${ }^{\circledR}$ program was used, which allowed the construction of the object in order to preserve the autonomy of the student through the hyperlink tool. This tool makes it possible to navigate between slides by clicking boxes created by the author. In addition, the function which allowed to move to the next screen was blocked and, thus, it was impossible the linear navigation, stimulating the student's autonomy and creativity.

The color scheme used was selected in conjunction with a nursing professional. In the virtual object, shades of blue predominated, which were used in the main menu, submenus of topics and titles of screens. In anatomy and semiology books, the veins are illustrated in blue, differing from arteries, which are represented by the red color, justifying the choice of color pattern.

After completing the computational modeling, we used the HTML5POINT ${ }^{\circledR}$ program, which allowed the virtual learning object to be saved in HTML format.

The HTML file was tested in different online browsers, such as Firefox, Internet Explorer and Google Chrome, which worked equally well on all three browsers. The object works offline in browsers, however in order for it to be implemented in the Moodle platform, the device must be connected to the internet. Therefore, in order to access the VLO, the student must have it made available by a teacher and a device connected to the internet.
In addition, the virtual object worked on different electronic devices, such as computers, notebooks, mobile phones and tablets. However, for standardization in the object evaluation stage, the notebook equipment was used.

\section{Ergonomic and pedagogical evaluation}

Once the construction was completed, the SEMIOVAPE evaluation process was started first with the experts. The stages of pedagogical evaluation and ergonomic evaluation occurred concomitantly during the month of April 2017.

Three experts participated in the ergonomic and pedagogical evaluation stages, all of which work in clinical nursing, female, with an average age of 38 years and an average of 15.3 years of experience in the area. Concerning the pedagogical evaluation of content, the average of the answers shows the agreement with the VLO, expressed by the categories "strongly agree" (92.3\%) and "agree" (7.7\%). There were no responses in the "disagree", "strongly disagree" and "do not know" categories. The experts recommended: replacement of some bibliographical references; inclusion of content on patient identification; route of access and frequency of medications used at home and addition of guidelines for practical activities; and use of more images in the item "Clinical Complications".

Ergonomic assessment by the experts was satisfactory, expressed by the data of the categories "strongly agree" (66.7\%) and "agree" (33.3\%). There were no responses to "disagree", 
"strongly disagree" and "do not know". Regarding the comments and suggestions, one suggested the correction of typing, evidencing the lack of space between one word and another; one expert recommended the standardization of repeating expressions; two experts suggested the addition and reallocation of hyperlinks in the "Test your knowledge" questions, so that the student had the possibility to return to the content. Still, two experts commented that the size of the source used could be larger. All the suggestions presented in the instrument of ergonomic and pedagogical evaluation of nursing were accepted by the authors.

Three other experts, all males, with an average age of 35.6 years and an average of 12.3 years of experience in Computer Science, also participated in the ergonomic evaluation. As for training, one is a Systems Analyst, one is a Data Processing Technologist and one is a Master in Computer Science. The average answers of the experts for the ergonomic evaluation categories were: "agree" (70.12\%); "strongly agree" (21.83\%); "disagree" (5.74\%); "strongly disagree" (1.15\%) and "do not know" (1.15\%).

In this step, there were suggestions for adding titles in some screens, placing abbreviations, adjusting the return of screens, reorganizing submenus, standardizing screens and correcting typing errors. The authors accepted all these suggestions. In addition, one expert suggested the placement of arrows on the screens, which would direct the student to the next content. However, it is a VLO of free navigation, which stimulates the creativity of the student; thus, these arrows could induce the student to follow a sequence, which would impair the precept of free navigation.

\section{Evaluation of the usability}

Participated on the study 20 Nursing undergraduates, target audience of SEMIOVAPE, with ages between 20 and 24 years, being four (20\%) with 20 years old, seven (35\%) aged 21 , seven (35\%) aged 22 and two (10\%) with 24 years. Of the participants, $10(50 \%)$ were from the Bachelor's Degree in Nursing, and 10 $(50 \%)$ from the Bachelor's and Nursing License Degree. As for the graduation period, 10 participants were enrolled in the $5^{\text {th }}$ period, seven (35\%) attended the $7^{\text {th }}$ and three (15\%) attended the $9^{\text {th }}$ period.

All participants considered the virtual object very useful and would certainly recommend it to a colleague. As to satisfaction, 19 of them (95\%) were certainly satisfied and one (5\%) was possibly satisfied.

The navigation of the virtual object seemed very interesting for 19 participants (95\%) and interesting for one (5\%); "much needed" for 18 of them (90\%) and "needed" for two (10\%). As to clarity, 19 participants $(95 \%)$ considered the navigation "very clear" and one (5\%) considered it "clear". All the participants considered the navigation "very informative", 19 (95\%) classified it as "very motivating" and one (5\%) as "motivating".

The information contained in the virtual learning object (contents) was classified by all the participants as "very interesting", "very necessary", "very clear" and "very informative".
Regarding the contribution, all the participants considered that the object will certainly bring some assistance to their role as a nurse.

Of the participants, $17(85 \%)$ reported that they did not present difficulties during navigation through the virtual learning object, two (10\%) pointed to the use of more images and one $(5 \%)$ reported that "relevance" and "map" topics could be written more clearly, better representing the content of the topics.

The target audience has shown interest in accessing virtual learning objects that address specific procedures and distinct areas of semiology. However, it was mentioned the interest in the use of such strategy in all the contents addressed in nursing teaching.

\section{DISCUSSION}

The results obtained in this study showed that the virtual learning object has aspects that can help the teacher in the teaching of the clinical examination, complementing the presence and theoretical teaching in Nursing, like other objects constructed in previous studies. ${ }^{15-27}$

The fulfillment of methodological steps in the construction of an educational material, in this case, SEMIOVAPE, allowed the selection of references, structuring of theoretical content and object modeling. As found in the literature, the construction process following steps ensures a better quality in the planning and development of VLOs. ${ }^{28}$

The construction of the object in a non-linear way allowed the student to offer free and flexible navigation for the content, adjusting it to the rhythm of each student's study, making the object motivating and interesting. ${ }^{27}$ The structuring of questions in the VLO contributes to the students being able to identify their weaknesses and monitor their performance, once again, favoring the students' autonomy and responsibility in their teachinglearning process. ${ }^{29}$

In this sense, the method used in the development of SEMIOVAPE was adequate to the proposed objectives of the object. The educational design and modeling stages allowed the pedagogical delineation of the object, including content choice, pedagogical model used and didactic organization of the subjects addressed, in order to encourage student autonomy during navigation.

Previous study has raised as a limiting factor the necessary financial resources for the construction of educational technologies. ${ }^{6}$ In this study, affordable and easy-to-use programs were used to construct the object, allowing accessibility to the VLO's edition. Thus, we recommend that the programs be used in further studies in the construction of innovative educational technologies.

The evaluation by nursing and informatics experts with experience in the area allowed the detection of errors and implementation of improvements in the VLO. If educational material is presented directly to the target audience without the appreciation of experts, content or design errors could discourage navigation or provide access to inappropriate 
content. In this sense, the prior validation of the VLO by specialists allowed it to be properly made available to its target audience. It was noted the importance of updating the selected references, standardizing the screens to facilitate navigation, adequate font size and content organization in a non-linear way. We consider that these aspects were fundamental for the production of quality educational material that would meet the objectives proposed. ${ }^{8}$

Considering that the traditional teaching model has been fragmented, ${ }^{3}$ this VLO consists of an alternative method of teaching the subject area, which may contribute to the teachinglearning of undergraduate students in Nursing, as it stimulates autonomy and interest in the study of the contents.

Younger generations, as in the case of graduates participating in this study, and nursing students have preference for alternative methodologies with the use of the Internet and are digital fluent, evidencing knowledge, skill and interest in the use of virtual objects. It is up to the educational institutions to identify the needs and preferences of their students to incorporate new learning methods. ${ }^{30,31}$

In the present study, the results of the usability evaluation with the target audience demonstrated a high level of satisfaction with SEMIOVAPE, similarly to what was found in a previous study, in which students agreed with the ease of navigating the object. ${ }^{30}$ In this sense, the VLO is characterized as a pleasant study environment, being a complementary tool to the classes. ${ }^{32}$ The interest in learning the most varied contents, using this technology, as reported by the participants, reinforces this understanding.

In spite of the limitation of the study having been carried out with students from only one institution, their data evidenced their rich contribution.

\section{CONCLUSIONS AND IMPLICATIONS FOR PRACTICE}

The methodological steps were adequate for the construction of the SEMIOVAPE, composed of the contents of anatomy and physiology, clinical complications, data collection, interview, physical examination and relevance of the data collection of this system. The fulfillment of the stages of the selected model was fundamental for the development of the VLO, since it allowed the organization of the resources and ensured the good quality of the material.

After construction of the VLO, this was considered valid by nursing experts as pedagogical (appearance, content coherence and adequacy to the learning-teaching proposal) and ergonomic (ease of navigation, clarity, presentation, functionality, and appearance) criteria; by computer experts on ergonomic criteria (page components, page groupings, menu titles, structure, icons, navigation, organization, content presentation and functionality); and, by the target public, as to its usability, who presented themselves satisfied and motivated with the object.
The results allow us to recommend SEMIOVAPE and make it available to nursing students, as a teaching strategy for peripheral venous vascular semiology. It is also expected, with this study, to stimulate the development of VLOs, tools to support teaching, on other topics related to nursing.

\section{FINANCING}

Research funded with Research Productivity Scholarship for the 5th author, by the National Council of Science and Technology (CNPq), Process no 305531/2013-1.

\section{REFERENCES}

1. Holanda VR, Pinheiro AKB, Pagliuca LMF. Aprendizagem na educação online: análise de conceito. Rev Bras Enferm [Internet]. 2013 May/ Jun; [cited 2017 Nov 15]; 66(3):406-11. Available from: http://dx.doi. org/10.1590/S0034-71672013000300016

2. Leite KNS, Santos SR, Andrade SSC, Zaccara AAL, Costa TF. The Internet and its influence in learning-teaching process of nursing students. UERJ Nurs J [Internet]. 2013 Oct/Dec; [cited 2017 Nov 10] 21(4):464-70. Available from: http://www.e-publicacoes.uerj.br/index. php/enfermagemuerj/article/view/10006/8132

3. Lira ANBC, Fernandes MICD, Costa IA, Silva RSC. Estratégia de aprimoramento do ensino do exame físico em enfermagem. Enferm Foco [Internet]. 2015; [cited 2017 Nov 10]; 6(1/4):57-61. Available from: http://revista.cofen.gov.br/index.php/enfermagem/article/view/578

4. Freire P. Pedagogia do oprimido. $17^{\mathrm{a}}$ ed. Rio de Janeiro: Paz e Terra 1987. [Internet]. Available from: http://files.portalconscienciapolitica. com.br/200000081-ed3e5ee3d0/Pedagogia\%20do\%200primido.pdf

5. Kahwage Neto SG, Braga TKK, Portella MC, Andriol RB. O Ensino de Habilidades Clínicas e a Aplicabilidade de um Guia Simplificado de Exame Físico na Graduação de Medicina. Rev Bras Educ Med [Internet] 2017 Apr/Jun; [cited 2017 Nov 08]; 41(2):299-309. Available from: http:// dx.doi.org/10.1590/1981-52712015v41n2rb20160110

6. Avelino CCV, Borges FR, Inagaki CM, Nery MA, Goyatá SLT. Desenvolvimento de um curso no Ambiente Virtual de Aprendizagem sobre a CIPE $®$. Acta Paul Enferm [Internet]. 2016 Jan/Feb; [cited 2017 Oct 20]; 29(1):69-76. Available from: http://dx.doi.org/10.1590/19820194201600010

7. Oliveira SN, Prado ML, Kempfer SS. Use of simulations in nursing education: an integrative review. Rev Min Enferm [Internet]. 2014 Apr/ Jun; [cited 2017 Oct 18]; 18(2):496-504. Available from: http://www. reme.org.br/artigo/detalhes/941

8. Góes FSN, Fonseca LMM, Camargo RAA, Oliveira GF, Felipe HR Educational technology "Anatomy and Vital Signs": Evaluation study of content, appearance and usability. Int J Med Inform [Internet]. 2015 Nov; [cited 2017 Oct 10]; 84(11):982-7. Available from: https://doi org/10.1016/j.ijmedinf.2015.06.005

9. Labegalini CMG, Previato GF, Dias GMS, Carreira L, Jaques AE, Baldissera VDA. O lazer em rede social virtual: uma possibilidade de diálogo autêntico. Esc Anna Nery [Internet]. 2017 Apr; [cited 2017 Dec 15]; 21(2):e20170037. Available from: http://www.scielo.br/scielo. php?script=sci_arttext\&pid=S1414-81452017000200209\&/ng=en\&n m=iso. http://dx.doi.org/10.5935/1414-8145.20170037

10. Salvador PTCO, Bezerril MS, Mariz CMS, Fernandes MID, Martins JCA, Santos VEP. Objeto e ambiente virtual de aprendizagem: análise de conceito. Rev Bras Enferm [Internet]. 2017 May/Jun; [cited 2017 Oct 18]; 70(3):572-9. Available from: http://www.scielo.br/scielo. php?script=sci_arttext\&pid=S0034-71672017000300572\&Ing=pt\&nr m=iso\&tlng=pt. DOI: http://dx.doi.org/10.1590/0034-7167-2016-0123.

11. Tognoli SH. Medida indireta da pressão arterial: avaliação de programa de educação permanente oferecido em dispositivo móvel [dissertação] Ribeirão Preto: Escola de Enfermagem de Ribeirão Preto - Universidade de São Paulo; 2012 
12. Braga CSR, Andrade EMLR, Luz MHBA, Monteiro AKC, Campos MOB, Silva FMS, et al. Construction and validation of a virtual learning object on intestinal elimination stoma. Invest Educ Enferm [Internet]. $2016 \mathrm{Jan} / \mathrm{Apr}$; [cited 2017 Oct 20]; 34(1):120-7. Available from: http://www.scielo.org.co/scielo.php?script=sci arttext\&pid=S0120-53072016000100014\&Ing=en\&nrm=iso. DOI: http://dx.doi.org/10.17533/udea.iee.v34n1a14.

13. Alvarez AG, Dal Sasso GTM. Aplicação de objeto virtual de aprendizagem, para avaliação simulada de dor aguda, em estudantes de enfermagem. Rev Latino Am Enferm [Internet]. $2011 \mathrm{Mar} /$ Apr; [cited 2017 Oct 15]; 19(2):1-9. Available from: http://www.scielo.br/pdf/rlae/ v19n2/pt_02

14. Calil FC, Peres HHC, Zaima J, Tobase L. A produção científica de objetos de aprendizagem no ensino em enfermagem. J Health Inform [Internet]. 2012 Dec; [cited 2017 Sep 30]; 4(n.esp SIIENF 2012):138-43. Available from: http://www.jhi-sbis.saude.ws/ojs-jhi/index.php/jhi-sbis/ article/view/245/134

15. Jarvis C. Physical Examination and Health Assessment. 6th ed. Philadelphia: Saunders; 2011.

16. Costa CPV, Luz MHBA. Digital learning object for diagnostic reasoning in nursing applied to the integumentary system. Rev Gaúcha Enferm [Internet]. 2015 Oct/Dec; [cited 2017 Oct 10]; 36(4):5562. Available from: http://www.scielo.br/scielo.php?script=sci arttext\&pid=S1983-14472015000400055\&Ing=en\&nrm=iso. DOI: http://dx.doi.org/10.1590/1983-1447.2015.04.54128

17. Tortora GJ, Nielsen MT. Princípios de anatomia humana. $12^{\mathrm{a}}$ ed. Rio de Janeiro: Guanabara Koogan; 2013.

18. Arreguy-Sena C, Carvalho EC. Superficial peripheral vein type classification of adolescents, adults and elderly according to the Delphi technique. Rev Latino Am Enferm [Internet]. 2008 Jan/Feb; [cited 2017 Oct 3]; 16(1):86-94. Available from: http://www.scielo.br/scielo. php?script=sci_arttext\&pid=S0104-11692008000100014\&lng=en\&n rm=iso. DOI: http://dx.doi.org/10.1590/S0104-11692008000100014

19. Herdman TH, Kamitsuru S. Diagnósticos de Enfermagem da NANDA: Definições e Classificação, 2015-2017. Porto Alegre: Artmed; 2015.

20. Bulechek GM, Butcher HK, Dochterman JM, Wagner CM. Nursing Interventions Classification (NIC). 6th ed. Saint Louis: Mosby; 2016.

21. Moorhead S, Johnson M, Maas ML, Swanson E. Nursing Outcomes Classification (NOC). 5th ed. Saint Louis: Mosby; 2012.

22. Bickley LS, Szilagyi PG. Bates' Guide to Physical Examination and History-Taking. 11th ed. Philadelphia: Wolters Kluwer Health; 2015.

23. Polit DF, Beck CT. Fundamentos da pesquisa em enfermagem: avaliação de evidências para a prática da enfermagem. $7^{\underline{a}}$ ed. Porto Alegre: Artmed; 2011.
24. Andrade AF, Franciosi B, Beiler A, Wagner PR. Requisitos para a modelagem de ambientes de aprendizagem a distância: uma proposta da PUCRS virtual. Porto Alegre; 2001. [Internet]. [cited 2017 Jun 10]. Available from: http://pesquisa.ead.pucrs.br/Artigos/Publicados/2001/ Aveiro/Aveiro_RequisitosModelagem.pdf

25. Goés FSN. Desenvolvimento e avaliação de objeto virtual de aprendizagem interativo sobre o raciocínio diagnóstico em enfermagem aplicado ao recém-nascido pré-termo [tese]. Ribeirão Preto: Escola de Enfermagem de Ribeirão Preto - Universidade de São Paulo; 2010.

26. Carvalho EC. Comportamento verbal enfermeiro-paciente: função educativa e educação contínua do profissional [tese]. Ribeirão Preto: Escola de Enfermagem de Ribeirão Preto da Universidade de São Paulo; 1985.

27. Holanda VR, Pinheiro AKB, Holanda ER, Santos MC. Ensino e aprendizagem em ambiente virtual: atitude de acadêmicos de enfermagem. Rev Min Enferm [Internet]. 2015 Jan/Mar; [cited 2017 Sep 29]; 19(1):141-7. Available from: http://pesquisa.bvs.br/aps/resource/ $\mathrm{pt} / \mathrm{bde}-26971$

28. Corradi MI, Silva SH, Scalabrin EE. Virtual objects to support the teaching-learning process of physical examination in nursing. Acta Paul Enferm [Internet]. 2011; [cited 2017 Oct 13]; 24(3):348-53. Available from: http://www.scielo.br/scielo.php?script=sci_arttext\&pid=S010321002011000300007\&lng=en\&nrm=iso. DOI: http://dx.doi.org/10.1590/ S0103-21002011000300007.

29. Trindade CS, Dahmer A, Reppold CT. Objetos de Aprendizagem: Uma Revisão Integrativa na Área da Saúde. J Health Inform [Internet]. 2014 Jan/Mar; [cited 2017 Oct 10]; 6(1):20-9. Available from: http://www. jhi-sbis.saude.ws/ojs-jhi/index.php/jhi-sbis/article/view/300

30. Costa PB, Prado C, Oliveira LFT, Peres HHC, Massarollo MCKB, Fernandes MFP, et al. Digital fluency and the use of virtual environments: the characterization of nursing students. Rev Esc Enferm USP [Internet]. 2011 Dec; [cited 2017 Nov 10]; 45(no.spe):158994. Available from: http://www.scielo.br/scielo.php?script=sci arttext\&pid=S0080-62342011000700008\&lng=en\&nrm=iso. DOI: http://dx.doi.org/10.1590/S0080-62342011000700008

31. Hampton D, Pearce PF, Moser DK. Preferred Methods of Learning for Nursing Students in an On-Line Degree Program. J Prof Nurs [Internet]. 2017 Jan/Feb; [cited 2017 Nov 15]; 33(1):27-37. Available from: http:// www.professionalnursing.org/article/S8755-7223(16)30119-3/fulltext. DOI: http://dx.doi.org/10.1016/j.profnurs.2016.08.004

32. Aredes ND, Góes FSN, Silva MAI, Gonçalves MFC, Fonseca LMM Objeto digital em enfermagem neonatal: impacto na aprendizagem de estudantes. Rev Eletr Enferm [Internet]. 2015 Oct/Dec [cited 2017 Nov 10]; 17(4):1-10. Available from: https://revistas.ufg.br/fen/article/ view/34856/20680 